\title{
Pembelajaran Kepada Masyarakat Kelurahan Lamaru RT 06 dan RT 17 untuk Meningkatkan Daya Minat Belajar
}

\author{
Ganjar Susilo $^{1 *}$; Prita Indriawati ${ }^{2}$; Retnowaty $^{3}$ \\ ${ }^{1}$ Universitas Balikpapan \\ 1*ganjar.susilo@uniba-bpn.ac.id
}

\begin{abstract}
Abstrak
Kegiatan pembelajaran kepada masyarakat di kelurahan lamaru RT 06 dan RT 17 merupakan kegiatan Pengabdian kepada Masyarakat yang dilakukan oleh dosen dan mahasiswa di lingkungan Universitas Balikpapan di Kelurahan Lamaru Balikpapan Timur, dengan tujuan untuk merealisasikan Tri Dharma Perguruan Tinggi dengan menerapkan nilai-nilai dan bentuk-bentuknya dalam kehidupan bermasyarakat dan bernegara, meningkatkan daya minat belajar masyarakat agar mendapatkan pendidikan yang lebih baik serta memberikan wawasan dan pengetahuan baru mengenai pendidikan dan dapat digunakan dalam kehidupan bermasyarakat di wilayah tempat tinggal masyarakat setempat. Metode dalam pengabdian kepada masyarakat di RT 17 dan RT 06 Kelurahan Lamaru adalah dengan cara melakukan Fokus Grup Diskusi (FGD). Hasil diskusi yang dilakukan yaitu 1) terbentuknya kerjasama antar tim pengabdian kepada masyarakat Universitas Balikkpapan sangat baik sehingga upaya-upaya untuk meningkatkan minat belajar masyarakat di Kelurahan Lamaru dapat berjalan dengan baik, 2) para peserta didik yang mengikuti kegiatan edukasi sangat aktif dalam kegiatan yang diberikan, seperti bimbingan belajar, lomba ketangkasan pengetahuan, serta eksperimen sederhana dalam membetuk pola model benda disekitar mereka dengan menggunakan media plastisin, dan 3) para pemuda berperan aktif dalam membantu kegiatan-kegiatan edukasi keterampilan berkarya.
\end{abstract}

Kata Kunci: minat belajar masyarakat, bimbingan belajar, lomba ketangkasan pengetahuan

\section{Abstract}

Learning activities for the community in the villages of Lamaru RT 06 and RT 17 were Community Service activities carried out by lecturers and students at the University of Balikpapan in Lamaru Village, East Balikpapan, with the aim of realizing the Tri Dharma of Universities by using their values and forms in community and state life, increase the power of interest in learning society in order to get a better education and provide new insights and knowledge about education and can be used in community life in the area where local people live. The method of community service in RT 17 and RT 06 of Lamaru Village by conducting Focus Group Discussions (FGD). The results of the discussion were 1) the formation of cooperation between the community service team of the University of Balikpapan very well so that efforts to increase the learning interest of the community in Lamaru Sub-District can run well, 2) the students who took part in educational activities were very active in the activities given, such as tutoring, knowledge dexterity competitions, and simple experiments in setting up model patterns of objects around them using plasticine media, and 3) young people playing an active role in helping education skills in creative activities.

Keywords: community learning interest, tutoring, knowledge agility competition

\section{Pendahuluan}

Setiap proses pembelajaran tentunya mengharapkan peserta didik memperoleh hasil belajar yang baik bagi dirinya sendiri maupun orang lain. Suatu hasil belajar siswa merupakan representasi kemampuan dan kualitas siswa sebagai dampak dari proses pembelajaran yang telah dilaluinya. Balistreri, Giacomo, Noisette, \& Ptak (2012, p. 5) menyiratkan bahwa hasil belajar merupakan tindakan dan pertunjukan yang mengandung dan mencerminkan kompetensi peserta didik yang berhasil menggunakan konten, informasi, ide-ide dan alat-alat dalam pembelajaran serta mampu memiliki keterampilan, pengetahuan, dan sikap khusus yang harus dikembangkan peserta didik agar menjadi kompeten secara global. Keterampilan dan pengetahuan yang dimiliki peserta didik harus diupayakan oleh guru dalam mengembangkan proses belajar mengajar di kelas atau diluar kelas. Menurut Gidley (2008, p.247) pendidikan di era globalisasi ini merupakan gambaran peserta didik yang memiliki pengetahuan, keterampilan dan sikap yang mengembangkan daya imajinatif kreatif dalam suatu proses belajar. Imajinasi kreatif yang diperlukan 
untuk mendorong transformasi pembelajaran ini ditunjukkan dengan penanaman imajinasi dalam pendidikan yang memungkinkan generasi muda untuk memiliki visi masa depan yang lebih positif, kreatif, dan berdaya. Ini tampaknya akan menjadi langkah penting dalam menciptakan masyarakat belajar dengan kebijaksanaan sebagai visi mereka.

Di tengah kuatnya arus kompetisi, maka perlu diadakannya suatu kegiatan yang terencana dan sistematis, serta aplikatif dan inovatif, untuk mendidikan dan melatih peserta didik agar menjadi intelektual muda yang profesional dan berkualitas, serta tanggap dalam menghadapi permasalahan yang timbul dalam kehidupan masyarakat, dan mampu memecahkan permasalahan tersebut. Pada proses pengabdian kepada masyarakat yang dilakukan melibatkan para mahasiswa-mahasiswa Fakultas Keguruan dan Ilmu Pendidikan Universitas Balikpapan sebanyak 10 orang. Keterlibatan mahasiswa ini sangat membantu dalam proses meningkatkan minat belajar masyarakat RT 06 dan RT 17 terutama pada anak-anak yang masuk kategori peserta didik dan sekaligus sebagai pengalaman mengajar bagi mahasiswa yang merupakan calon-calon guru dalam menghadapi peserta didik dalam proses belajar mengajar disekolah. Menumbuh kembangkan minat belajar masyarakat di kelurahan Lamaru tidaklah mudah, dikarenakan kondisi masyarakat sekitar yang rata-rata pekerjaan hariannya adalah sebagai nelayan. Disisi lain, berdasarkan hasil observasi bersama dengan Lurah Kelurahan Lamaru, menyampaikan siswa putus sekolah didaerah tersebut juga banyak dikarenakan faktor ekonomi, kurangnya perhatian orang tua peserta didik terhadap kualitas pendidikan anak, kurangnya kemampuan membaca dan menulis yang mengakibatkan masyarakat disekitar kelurahan Lamaru kesulitan dalam pengurusan administrasi yang berkaitan dalam kehidupan seharihari, Kurangnya pemahaman orang tua mengenai pendidikan tinggi sehingga menyebabkan menurunya motivasi anak untuk bersekolah ke jenjang yang lebih tinggi dan kurangnya kesadaran akan pentingnya sekolah untuk pendidikan yang lebih baik.

Berdasarkan pendapat Nurhasanah \& Sobandi (2016, p. 136) menyatakan bahwa jika minat belajar seseorang kurang baik akan mengakibatkan keterampilan, pengetahuan, dan sikap seorang dalam belajar akan rendah dan tidak memiliki kompetensi keilmuan yang baik, begitu pula sebaliknya, jika minat belajar seseorang baik atau tinggi, maka keterampilan, pengetahuan dan sikap dalam belajar akan baik pula serta memiliki kompetensi yang baik dan bisa bermanfaat bagi orang lain. Hal ini sejalan dengan Sardini, Buwono, \& Parijo (2013, p. 2) menyataan minat belajar sangat berpengaruh sangat penting pada kegiatan seseorang, ketika minat belajarnya baik maka seseorang tersebut akan mengerjakan dan melakukannya, jika tidak ada minat belajarnya maka seseorang tersebut tidak akan melakukannya walaupun disuruh atau diperintahkan oleh orang lain.

Oleh karena itu, proses peningkatan daya minat belajar di kelurahan Lamaru harus ditingkatkan terutama di RT 06 dan RT17, agar terciptanya kesadaran dan motivasi untuk belajar semakin tinggi sehingga angka tingkat anak-anak yang putus sekolah dapat diturunkan dan menyadarkan kepada orang tua peserta didik akan pentingnya suatu pendidikan disekolah. Berdasarkan permasalah tersebut perlu dilakukan kegiatan yang dapat membangkitkan minat belajar masyarakat Kelurahan Lamaru terutama di RT 06 dan RT 17 yaitu dengan cara memberikan penyuluhan kepada masyarakat akan pentingnya pendidikan anak untuk wajib belajar 9 tahun, melakukan sosialisasi kesekolah-sekolah yang berada di kawasan Kelurahan Lamaru dengan tema "Pendidikan Untuk Masa Depan Lebih Baik", mengadakan lombalomba kegiata anak-anak yang mengandung unsur pembelajaran disekolah, dan perbaikan administrasi disekolah-sekolah yang masih membutuhkan.

\section{Bahan dan Metode}

Kunjungan pengabdian kepada masyarakat dilaksanakan oleh 3 dosen dan 10 mahasiswa Universitas Balikpapan dengan Lurah Kelurahan Lamaru Kecamatan Balikpapan Timur dengan sasaran kegiatan yakni meningkatkan daya minat belajar masyarakat agar mendapatkan pendidikan yang lebih baik di RT 06 dan RT 17 Kelurahan Lamaru Kecamatan Balikpapan Timur. Pengabdian kepada masyarakat dilaksanakan oleh 3 dosen Universitas Balikpapan yaitu Ganjar Susilo, S.Pd.,M.Pd, Prita Indriawati, S.Pd.,M.Pd, dan Retnowaty, S.Pd.,M.Pd serta dibantu dengan 10 orang mahasiswa Fakultas Keguruan dan Ilmu Pendidikan Universitas Balikpapan yaitu Ali Agra Tama, Ayu Puspita Sari, Darin Nadhifah, Duwi Masitah, Kiki Wahyuningsih, Lusi Ambarani, Maya Agus Cahyani, Ni'matur Rohmah, Novia Dwi Puspita Sari dan Siti Rahma Lubis.

Kegiatan ini dilaksanakan selama 3 bulan dari tanggal 5 November 2018 sampai 25 Januari 2019. Tempat Pelaksanaan adalah di RT 06 dan RT 17 Kelurahan Lamaru Kecamatan Balikpapan Timur, dengan susunan kegiatan sebagai berikut:

\section{Tabel 1.}

Susunan Kegiatan

\begin{tabular}{|c|c|}
\hline $\begin{array}{l}\text { Tanggal/Bulan/ } \\
\text { Tahun }\end{array}$ & Kegiatan \\
\hline \multirow{4}{*}{$\begin{array}{c}\text { 5-20 November } \\
2018\end{array}$} & 1) Penyuluhan tim Pengabdian \\
\hline & Kepada Masyarakat (PkM) \\
\hline & $\begin{array}{l}\text { Universitas Balikpapan dengan } \\
\text { warga mengenai kegiatan yang } \\
\text { akan dilakukan. }\end{array}$ \\
\hline & $\begin{array}{l}\text { 2) Pendataan tingkat pendidikan } \\
\text { warga dan pendataan faktor }\end{array}$ \\
\hline
\end{tabular}




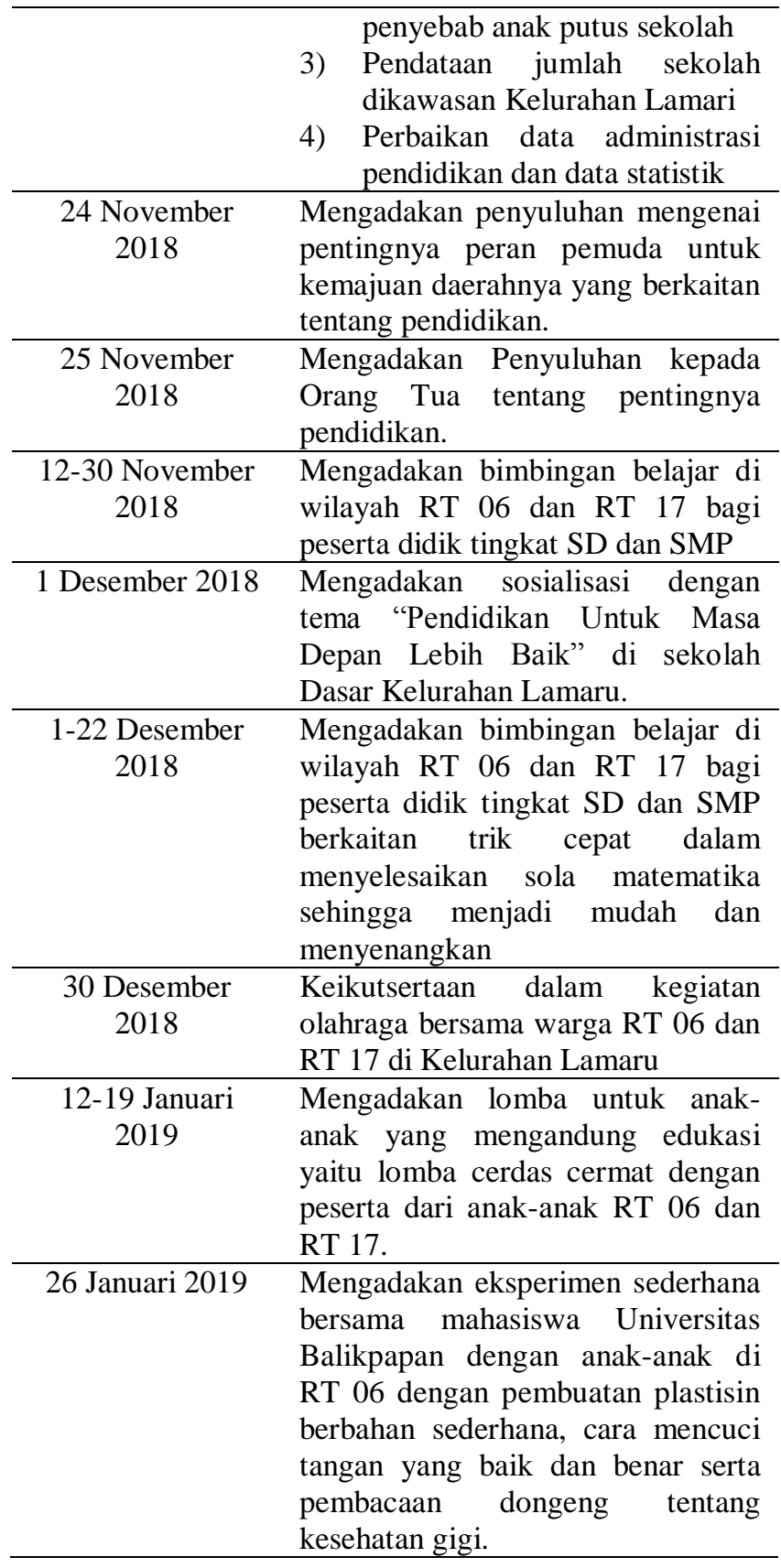

\section{Hasil dan Pembahasan}

Kegiatan untuk upaya meningkatkan daya belajar masyarakat RT 06 dan RT 17 di Kelurahan Lamaru bekerjasama dengan Lurah Kelurahan Lamaru antara lain adalah mengadakan penyuluhan antara tim pengabdian kepada masyarakat yang dibantu mahasiswa Universitas Balikpapan mengadakan penyuluhan bersama warga dengan cara forum grup diskusi (FGD) di rumah Ketua RT 06. Bentuk kegiatan yang dilakukan adalah diskusi tentang permasalahan pendidikan yang berkaitan mengidentifikasi penyebab peserta didik di wilayah tersebut putus sekolah. Hasil wawancara dengan Ketua RT 06 ditemukan permasalahan pendidikan yaitu.

1) Peserta didik putus sekolah dikarenakan pergaulan bebas,
2) Peserta didik putus sekolah dikarenakan faktor ekonomi keluarga,

3) Kurangnya pemahaman orang tua peserta didik mengenai pendidikan yang tinggi,

4) Cepat merasa puas dengan jenjang pendidikan yang dimiliki saat ini,

5) Kurangnya kesadaran peserta didik untuk bersekolah dan melanjutkan sekolah yang lebih tinggi.

Sedangkan permasalahan pendidikan yang ditemukan di RT 17 adalah,

1) Kurangnya kemampuan membaca dan menulis masyarakat,

2) Ada ditemukan masyarakat atau warga di RT 17 yang masih buta huruf,

3) Kurangnya perhatian dan pengawasan oleh orang tua kepada anak-anak terhadap waktu belajar mereka disekolah dan dirumah.

Berdasarkan hasil temuan tersebut maka tim pengabdian masyarakat melakukan upaya-upaya untuk mengubah pola pikir masyarakat akan pentingnya pendidikan dan pengawasan pendidikan agar anak-anak yang masih bersekolah dan remaja-remaja di RT 06 dan RT 17 tidak putus sekolah dan tidak terjerumus pada pergaulan bebas yang mengakibatkan mereka putus sekolah. Upaya-upaya untuk menarik masyarakat untuk peduli dengan pendidikan, yaitu.

1) Mengadakan sosialisasi dengan tema "Pendidikan Untuk Masa Depan Lebih Baik" di Sekolah Dasar Negeri (SDN) 005 dan Sekolah Dasar Negeri 018 Kelurahan Lamaru. Kegiatan tersebut diisi dengan forum grup diskusi (FGD) bersama kepada perwakilan orang tua murid dan guru.

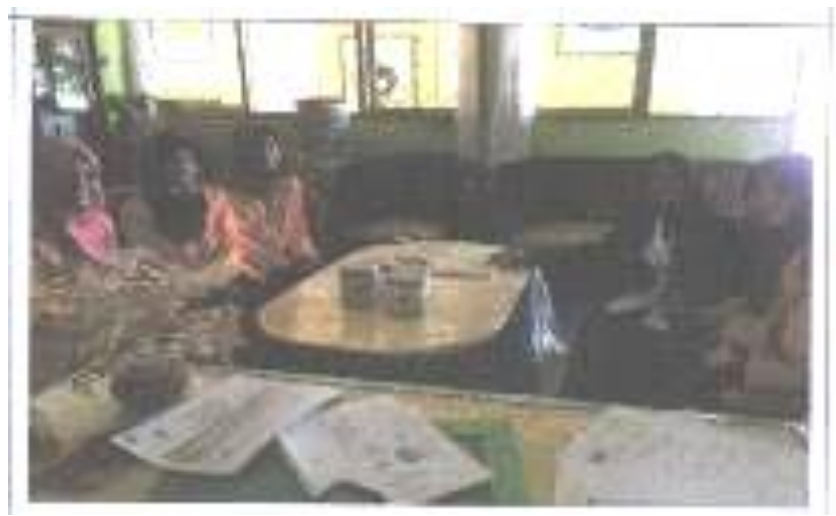

Gambar 1. Forum Grup Diskusi Bersama Wali Peserta Didik dan Guru

Dalam forum grup diskusi (FGD) yang dilakukan diperoleh pemahaman tentang karakteristik peserta didik yang putus sekolah, kurang bisa membaca kalimat dengan jelas dan lancar, serta kurangnya memahami materi ajar yang diajarkan disekolah. Setelah kegiatan forum grup diskusi selesai dilakukan tim pengabdian kepada masyarakat bersama mahasiswa Universitas Balikpapan melakukan 
sosialisasi kelas-kelas tentang pentingnya pendidikan untuk masa depan.

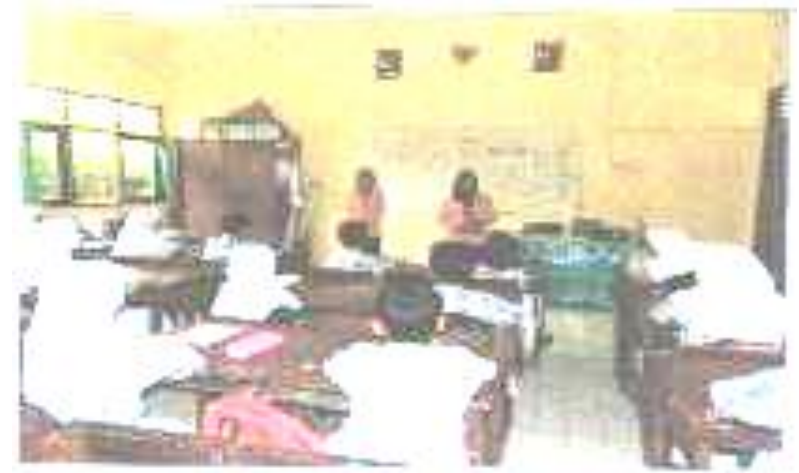

Gambar 2. Penyampaian Sosialisasi Pendidikan

Penyampaian sosialisasi yang dilakukan dikelas $\mathrm{V}$ dan VI sekolah dasar kepada siswa berupa konsep dasar dalam proses pendidikan dan pembelajaran yang dilakukan. Peserta didik diajak untuk terus melanjutkan sekolahnya hingga jenjang pendidikan tinggi dan menanamkan budaya membaca sejak dini, agar ketika sudah masuk dunia kerja peserta didik sudah siap menjadi individu yang mempunyai potensi keahlian bekerja lebih baik.

2) Mengadakan bimbingan belajar di wilayah RT 17 Kelurahan Lamaru yang dilakukan setiap hari Selasa dan Kamis dalam kurun waktu dua bulan. Pelaksanaan bimbingan belajar dilakukan pada pukul 15.00 wite.

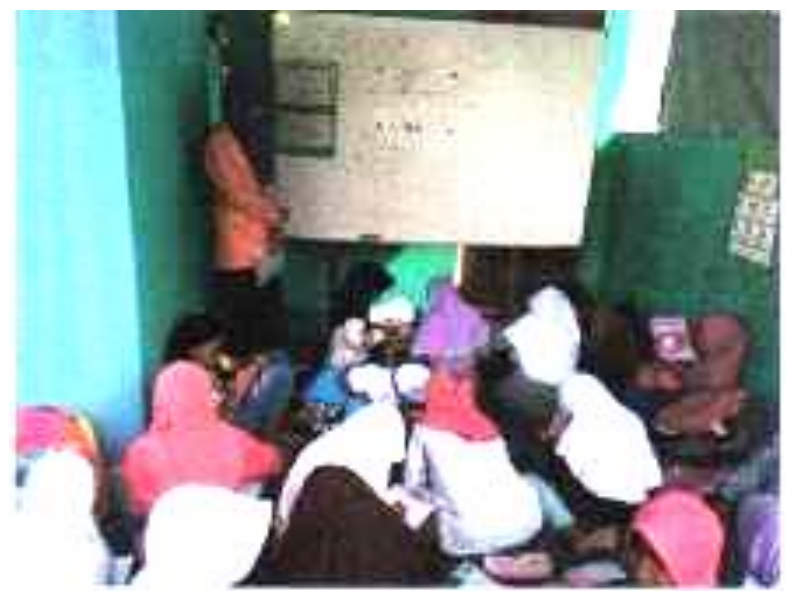

Gambar 3. Proses Bimbingan Belajar di RT 17 Kelurahan Lamaru

Proses bimbingan belajar yang dilakukan berupa pembelajaran baca tulis kepada peserta didik yang belum lancar dalam membaca buku teks dan menuliskan huruf abjad dengan baik dan benar. Langkah-langkah yang dilakukan dalam proses belajar membaca cepat dengan cara memberikan bacaan cerita bergambar dan praktik menerangkan cerita bergambar.

3) Melakukan kegiatan cerdas cermat di Sekolah Dasar Negeri (SDN) 005 Kelurahan Lamaru.

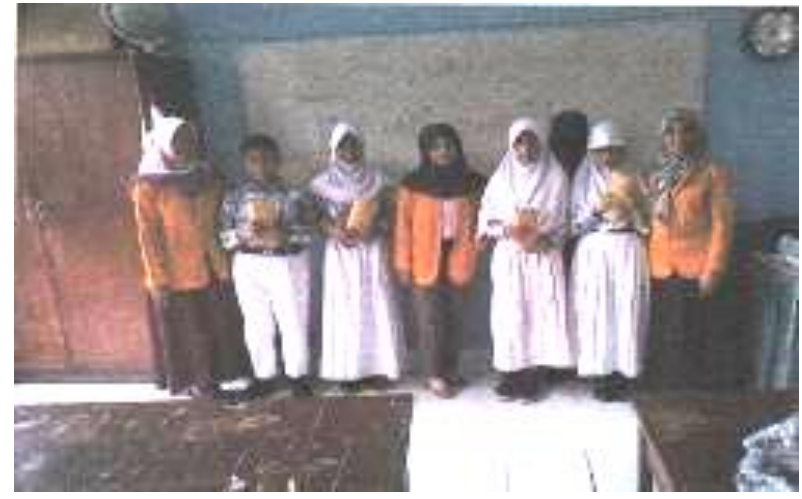

Gambar 4. Penyerahan Hadiah Kepada Pemenang Lomba Cerdas Cermat Matematika

Lomba cerdas cermat dilakukan untuk melatih kemampuan pengetahuan pada peserta didik tentang materi sekolah yang telah dipelajari serta membantu peserta untuk cepat dan tanggap dalam belajar.

4) Mengadakan penyuluhan mengenai pentingnya peran pemuda untuk kemajuan daerahnya yang berkaitan tentang pendidikan

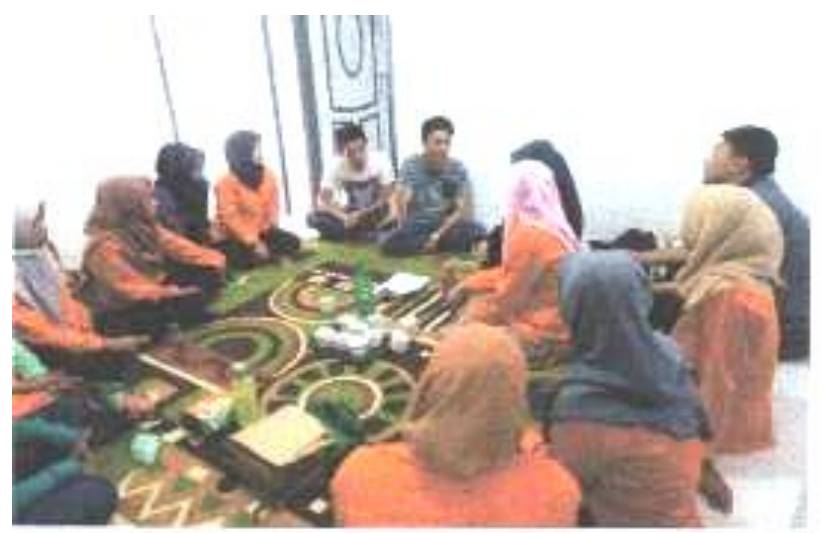

Gambar 5. Penyuluhan Kepada Pemuda di RT 06

Penyuluhan yang dilakukan berupa pemahaman kepada para pemuda untuk berperan aktif membawa perubahan pembelajaran keahlian berkarya, baik segi pengetahuan, pemahaman, keterampilan maupun sikap agar ketika masuk dunia kerja, mereka mampu beradaptasi dengan perubahan dunia kerja yang berkembang sangat pesat.

5) Melakukan lomba keterampilan pengetahuan "RANKING 1" di RT 06 dan RT 17. 


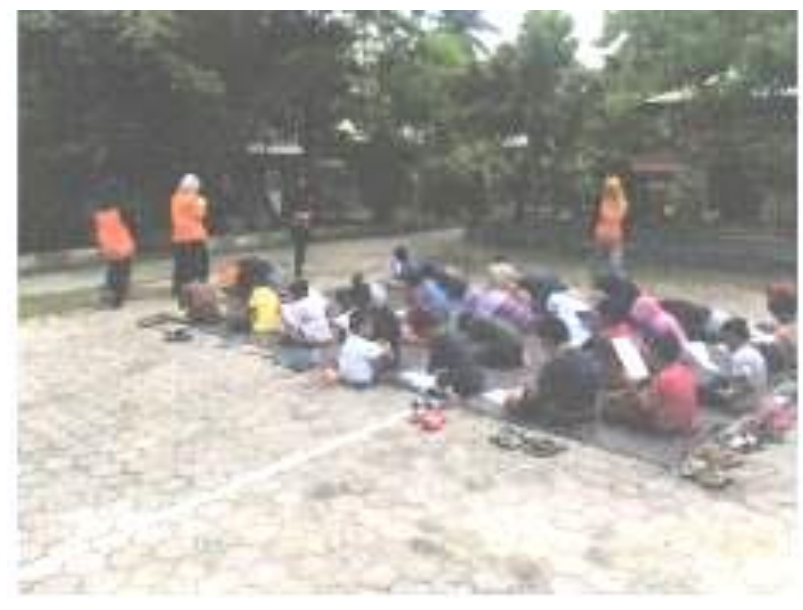

Gambar 6. Pelaksanaan Lomba RANKING 1

Lomba "RANKING 1" dilaksanakan untuk menarik perhatian peserta didik di sekitar RT 06 dan RT 17 untuk menguji kemampuan pengetahuannya dengan cepat serta memberikan apresiasi kepada peserta berupa hadiah hiburan kepada peserta didik yang mampu menjawab dengan benar pertanyaan yang di berikan.

6) Mengadakan eksperimen sederhana bersama mahasiswa Universitas Balikpapan dengan anak-anak di RT 06 dengan pembuatan plastisin berbahan sederhana, cara mencuci tangan yang baik dan benar serta pembacaan dongeng tentang kesehatan gigi

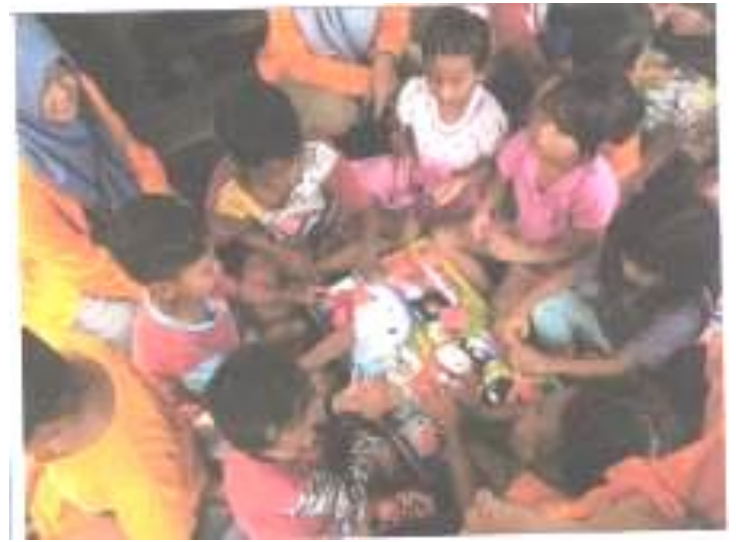

Gambar 7. Ekperimen Sederhana Bersama Peserta Didik di RT 06

\begin{abstract}
Ekperimen plastisin yang dilakukan untuk membangun kreatifitas peserta didik dalam memahami bentuk-bentuk di sekitar mereka dan membentuknya melalui media belajar plastisin yang diberikan. Setelah melakukan eksperimen ini para peserta didik diajak untuk mencuci bersih tangan setelah beraktivitas menggunakan plastisin.
\end{abstract}

Permasalahan pendidikan di Kelurahan Lamaru terutama di RT 06 dan RT 17 adalah Siswa putus sekolah dikarenakan pergaulan bebas dan faktor ekonomi keluarga. Selain kedua faktor tersebut orang tua kurang memahami pendidikan tinggi untuk masa Volume 1, Nomor 1, 2019

ISSN 2657-1439 depan yang lebih baik. Menurut Marsiti (2011, p. 157) pendidikan yang baik untuk peserta didik adalah adanya kerjasama pihak sekolah dan orang tua dalam meningkatkan kualitas pendidikan berupa penyempurnaan kurikulum belajar anak, dan perbaikan sarana dan prasarana sekolah. Disamping itu, dirumah peserta didik peran pendidikan keluarga terutama partisipasi orang tua dalam mengawasi proses belajar anak sangat diperlukan dan dukungan berupa fisik dan moril sangat diperlukan agar peserta didik termotivasi untuk belajar. Lingkungan keluarga mempunyai peran yang sangat kuat terhadap perkembangan kepribadan peserta didik, karena sebagian besar kehidupan anak berada di tengah-tengah keluarga. Mengupayakan kemampuan dan kepribadian anak, orang tua harus menumbuhkan suasanan edukatif di lingkungan keluarganya sedini mungkin. Hal ini senada dengan Wahyuni \& Palupiningdyah (2017, p. 50) yang menyatakan bahwa sebelum proses belajar mengajar dilakukan, peserta didik harus dibangun minat belajarnya dengan cara memberikan pelajaran produktif menyenangkan berupa pemberian aktifitas belajar di luar kelas dan memberikan ice breaking ditengah-tengah proses pembelajaran agar peserta didik tidak bosan dengan pelajaran yang diberikan oleh guru. Pembelajaran dan latihan yang diberikan merupakan interaksi yang bernilai normatif dan edukatif, oleh karena itu pembelajaran adalah suatu proses yang dilakukan dengan sadar dan bertujuan untuk mendapatkan pendidikan sebaik-baiknya (Munirah, 2014, p. 80)

Sudjana (2013, p. 11) menyatakan proses pembelajaran suatu pengajaran di sekolah terjadi apabila ada interaksi antara peserta didik dengan lingkungan belajar yang dipersiapkan dan diatur oleh guru untuk mencapai tujuan pelajaran. Guru dan orang tua dalam mempersiapkan keberhasilan peserta didik merupakan komponen yang sangat berpengaruh terhadap terciptanya proses dan hasil pendidikan yang berkualitas. Guru yang profesional dan berkompeten akan mampu menciptakan lingkungan belajar yang efektif dan akan lebih mampu mengelola kelasnya sehingga hasil belajar peserta didik berada pada tingkat yang maksimal. Upaya-upaya lain dalam meningkatkan minat belajar yaitu dengan melaksanakan lomba cerdas cermat kepada peserta didik dengan tujuan untuk membangun komunikasi pembelajaran. Komunikasi pembelajaran sangat penting dilakukan agar indera-indera peserta didik aktif karena digunakan dan terlibat langsung dengan proses belajar. Semakin alat inderanya digunakan untuk menerima dan mengolah informasi, maka semakin besar pula kemungkinan informasi tersebut dipahami dan dipertahankan dalaman ingatan sehingga pada akhirnya peserta didik dapat mudah menyerap dengan baik materI yang disampaikan (Munirah, 2014, p. 81). Adanya 
lomba pengetahuan ini akan memberikan rangsangan belajar kepada peserta didik sehingga orang tua akan memberikan dukungan kepada anaknya agar terus berupaya belajar lebih giat agar mampu bersaing pengetahuan dengan anak-anak yang lainnya. Selain mengadakan lomba pengetahuan para peserta didik juga mendapatkan bimbingan belajar berupa membaca cerita bergambar yang dipresentasikan didepan temantemannya. Kegiatan ini melatih siswa apabila mempelajari sesuatu hal akan bermakna bagi dirinya, membentuk pengetahuan yang baru dari pengalaman yang baru dilakukan, serta peserta didik dilatih untuk bertanggung jawab dalam proses pembelajaran dan mampu mengevaluasi kekurangan dalam dirinya jika salah-salah dalam menerangkan cerita bergambar (Hanafy, 2014, p. 70).

Peran masyarakat dalam memajukan pendidikan di RT 17 dan RT 06 sangat besar pengaruhnya dalam membentuk kepribadian dan perilaku sosial anak, karena masyarakat akan diajak secara langsung menjadi pengawas dan monitoring kegiatan-kegiatan yang dilakukan oleh peserta didik. Pengawasan ini bermanfaat untuk menjaga peserta didik di RT 17 dan RT 06 dari pengaruh-pengaruh negatif lingkungan sekitar mereka. Peran yang telah dibangun oleh masyarakat berupa sosialisasi kepada anak untuk mengajak dan mendorong mengikuti kegiatan-kegiatan positif seperti pengajian, bakti sosial (baksos), gotong royong dan lain-lain. Keikutsertaan peserta didik juga membantu memperoleh bekal ilmu serta simpati dan empati terhadap sesame masyarakat sehingga anak dapat berkepribadian dan perilaku yang bak dalam berinteraksi dengan lingkungan sekitar (Wardian \& Suryatman, 2018, p. 144)

\section{Kesimpulan dan Saran}

Simpulan yang dapat diambil dari kegiatan pengabdian masyarakat yang dilakukan adalah.

1) Kerjasama antar tim pengabdian kepada masyarakat Universitas Balikkpapan sangat baik sehingga upayaupaya untuk meningkatkan minat belajar masyarakat di Kelurahan Lamaru dapat berjalan dengan baik.

2) Para peserta didik yang mengikuti kegiatan edukasi sangat aktif dalam kegiatan yang diberikan, seperti bimbingan belajar, lomba ketangkasan pengetahuan, serta eksperimen sederhana dalam membetuk pola model benda disekitar mereka dengan menggunakan media plastisin.

3) Para pemuda berperan aktif dalam membantu kegiatan-kegiatan edukasi keterampilan berkarya.

Saran yang dapat diberikan kepada para peserta didik dan masyarakat sekitar Kelurahan Lamarru terutama warga RT 17 dan RT 06, proses pendidikan yang telah dilakukan seharusnya dapat dilakukan secara berkelanjutan agar pendidikan di wilayah tersebut dapat semakin baik lagi dan mampu mengurangi para peserta didik putus sekolah.

\section{Ucapan Terima Kasih}

Tiada kata yang pantas diucapkan melainkan memanjatkan puja dan puji syukur kehadirat Allah SWT. Karena berkat Rahmat, Hidayah dan Inayah-Nya jurnal pengabdian kepada masyarakat telah selesai dengan baik. Selama proses kegiatan ini berlangsung, penulis banyak sekali mendapat pengalaman berharga, nasihat-nasihat dan dukungan dari berbagai pihak. Namun demikian bukan berarti tak luput dari berbagai cobaan dan rintangan yang menghadang. Pada kesempatan ini penulis mengucapkan terima kasih yang sebesar-besarnya kepada:

1) Dr. Piatur Pangaribuan, A.Md.,S.H.,M.H.,C.L.A sebagai Rektor Universitas Balikpapan yang telah memberikan kesempatan melaksanakan kegiatan pengabdian kepada masyarakat di kelurahan Lamaru.

2) Merry K Sipahutar, S.Pi.,M.Si.,P.Hd sebagai Ketua Lembaga Penelitian dan Pengabdian Kepada Masyarakat (LPPM) atas dukungan yang diberikan.

3) Istri dan anak, serta bimbingan orang tua, sehingga kendala-kendala yang penulis hadapi terselesaikan dengan baik.

4) Berbagai pihak yang telah membantu terlaksananya penelitian ini.

\section{Daftar Rujukan}

Balistreri, S., Giacomo, F. T. Di, Noisette, I., \& Ptak, T. (2012). Global Education: Connections, Concepts, and Careers. Retrieved from https://files.eric.ed.gov/fulltext/ED562681.pdf

Gidley, J. (2008). Beyond Homogenisation of Global Education. Retrieved from https://researchbank.rmit.edu.au/view/rmit:39 42/g2006012285.pdf

Hanafy, M. S. (2014). Konsep Belajar dan Pembelajaran. Jurnal Lentera Pendidikan, XVII(1), 66-79. Retrieved from http://journal.uinalauddin.ac.id/index.php/lentera_pendidikan/a rticle/viewFile/516/491

Marsiti, C. I. R. (2011). Upaya Peningkatan Mutu Pendidikan Sekolah Menengah Kejuruan Melalui Pengembangan Profesionalisme Guru. Jurnal Pendidikan Vokasi, 1(1), 157-168. Retrieved from https://journal.uny.ac.id/index.php/jpv/article/ view/5810/5010

Munirah. (2014). Upaya Peningkatan Mutu Hasil Belajar Melalui Media Pembelajaran. Jurnal Pendidikan Dasar Islam Auladuna, 1(1), 8088. Retrieved from http://journal.uin- 
alauddin.ac.id/index.php/auladuna/article/view $1543 / 538$

Nurhasanah, S., \& Sobandi, A. (2016). Minat Belajar Sebagai Determinan Hasil Belajar Siswa. Jurnal Pendidikan Manajemen Perkantoran, I(1), 135-142. Retrieved from http://ejournal.upi.edu/index.php/jpmanper/art icle/view/3264/2338

Sardini, Buwono, S., \& Parijo. (2013). Pengaruh Minat Belajar Terhadap Hasil Belajar Pelajaran Ekonomi Siswa Kelas XI IPS MAN Pontianak. Jurnal Pendidikan Dan Pembelajaran, II(7), 1-17. Retrieved from http://jurnal.untan.ac.id/index.php/jpdpb/articl e/view/2777/pdf

Sudjana, N. (2013). Dasar-dasar Proses Belajar Mengajar. Bandung: Sinar Baru Algesindo.

Wahyuni, K., \& Palupiningdyah. (2017). Pengaruh
Kompetensi Profesional Guru, Lingkungan Keluarga, Dan Fasilitas Belajar Terhadap Minat Belajar Siswa Kelas X Administrasi Perkantoran di SMK Pangudi Luhur Tarcisius 1 Semarang. Economic Education Analysis Journal, VI(1), 47-58. Retrieved from https://journal.unnes.ac.id/sju/index.php/eeaj/a rticle/view/13472/7355

Wardian, I., \& Suryatman. (2018). Peran Lingkungan Keluarga Dan Masyarakat Dalam Membentuk Kepribadian dan Perilaku Sosial Anak Usia SMP Di Wilayah Pesisir Mundu Kabupaten Cirebon. Jurnal Edueksos, VII(2), 133-146. Retrieved from http://syekhnurjati.ac.id/jurnal/index.php/edue ksos/article/view/3165/2020 